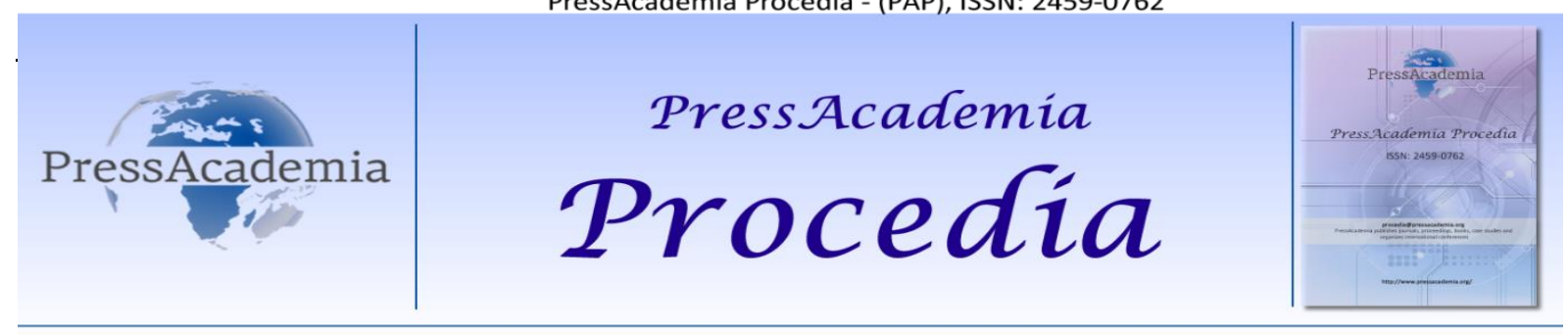

Global Business Research Congress (GBRC), May 24-25, 2017, Istanbul, Turkey.

\title{
A STUDY ON REAL ESTATE APPRAISAL AND ASSESMENT REPORTS CONDUCTED IN TURKEY
}

DOI: 10.17261/Pressacademia.2017.678

PAP-GBRC-V.3-2017(105)-p.972-985

Huseyin Mert ${ }^{1}$, Remzi Aydin ${ }^{2}$

${ }^{1}$ Okan University. huseyin.mert@okan.edu.tr

${ }^{2}$ Okan Univeristy. remzi_aydin@hotmail.com

To cite this document

Mert, H. and R. Aydin, (2017). A study on real estate appraisal and assesment reports conducted in Turkey. PressAcademia Procedia (PAP), V.3, p.972-985.

Permemant link to this document: http://doi.org/10.17261/Pressacademia.2017.678

Copyright: Published by PressAcademia and limited licenced re-use rights only.

\begin{abstract}
Real estate appraisal activity is the determination of the likely value of the real estate together with its rights and benefits on a certain date. Real estate appraisal report has to be organized by real estate appraisal experts who are lisenced by SPK ( Sermaye Piyasası Kurumu ) in Turkey. The related legal rights are arranged by SPK and BDDK (Bankacılık Denetleme ve Düzenleme Kurumu) in their published regulations and documentaries and notifications. The real estate appraisal reports prepared in Turkey has to be prepared according to International Appraisal Standards and be in conformity with both Turkish Financial Report Standards and International Evaluation Standards. In this study, the structure and evaluation methods of real estate appraisal reports prepared in Turkey has been investigated in the light of Turkish Financial Report Standards and International Evaluation Standards. Also, taking into account the fact that accounting principles and financial tables should reflect the reality; we criticize them and suggested some solutions.
\end{abstract}

Keywords: Real estate appraisal report, valuation, international evaluation standards, Turkish Financial Reporting Standards. JEL Codes: M41, M42

\section{GAYRIMENKUL DEĞERLEME VE TÜRKIYEDE YAPILAN DEĞERLEME RAPORLARI ÜZERINE BíR ARAŞTIRMA}

\section{ÖZET}

Gayrimenkul değerleme faaliyeti, gayrimenkul ve gayrimenkule bağlı olan hak ve faydaların belli bir tarihteki muhtemel değerinin belirlenmesidir. Gayrimenkul değerleme raporu, gayrimenkulün değerinin belirlenmesi için Sermaye Piyasası Kurulu tarafından yetkilendirilmiş kuruluşlarca, Lisanslı Değerleme Uzmanları tarafından düzenlenir. Gayrimenkul Değerleme Raporlarına ilişkin hukuki düzenlemeler, Sermaye Piyasası Kurulu ve Bankacılık Düzenleme ve Denetleme Kurulu tarafından çıkarılan çeşitli tebliğ ve yönetmeliklerle düzenlenmiştir. Türkiye' de düzenlenen değerleme raporları, çeşitli değerleme yöntemlerine göre Uluslararası Değerleme Standartlarına uygun olarak hazırlanması gerekmektedir. Türkiye Finansal Raporlama Standartları açısından gayrimenkul değerleme raporlarının düzenlenmesi gerektiği zaman bunların her iki standart açısından da uygun olması gerekmektedir. Bu çalışmada Türkiye' de düzenlenen gayrimenkul değerleme raporlarının yapıları, kullanılan değerleme yöntemleri incelenerek Uluslararası Değerleme Standartları ve Türkiye Finansal Raporlama Standartları açııından değerlendirilmiştir. Ayrıca muhasebe ilkeleri ve finansal tabloların gerçeği yansıt ması açısından sonuçlar değerlendirilip çözüm önerileri getirilmesi amaçlanmıştır.

Anahtar Kelimeler: Gayrimenkul değerleme raporu, değerleme, Uluslararası Değerleme Standartları, Türkiye Finansal Raporlama Standartları

JEL Kodları: M41, M42 


\section{GíRiş}

İşletmelerin finansal tablolarının şeffaf olması ve gerçeği yansıtması için değerlemelerin uluslararası normlara uygun olması gerekmektedir. Bu gereksinim uluslararası uyum gereği, yabancı yatırımcıların ülkemize gelmesi açısından ve uluslararası ticaretin gelişmesi açısından çok önemlidir. Değerleme işlemi, işletmeler için vergi, finansal tabloların gerçek durumu yansıtması ve yatırımcı kararları açısından çok önemli bir konudur. Gayrimenkul değerlemesi raporlarının Uluslararası Değerleme Standartlarına uyularak hazırlanması gerekmektedir. Bu konu SPK, BDDK mevzuatına tabi işletmelerde düzenlenmiş, TMS' de önerilmiş, diğer mevzuata tabi işletmelerde ise kredi amaçlı kullanımın yaygın olduğu görülmektedir. Bu çalışmada, ülkemizdeki gayrimenkul değerleme raporlarının, Uluslararası Değerleme Standardı ve Uluslararası Muhasebe Standartları arasındaki uyum sorunları sebebiyle oluşan problemlerin neler olabileceği, değerleme firmalarına yaptırılan değerleme raporlarının finansal tablolara etkilerinin neler olduğu, problemlerin nasıl giderilebileceği, nelere dikkat edilmesi gerektiği anlatılmıştır. Uygulama çalışmasında piyasada son yıllarda yapılmış olan gayrimenkul değerleme raporları incelenmiş olup gayrimenkul değerleme raporlarında kullanılan değerleme yöntemleri, hangi değerleme yönteminin seçildiği, kapitalizasyon oranlarının, brüt kira çarpanlarının yıl olarak ne olduğu, emsal fiyatların nerelerden, nasıl temin edildiği, değerleme raporlarındaki eğilimlerin ne olduğu saptanmaya çalışılmıştır. Araştırma sonunda gayrimenkul değerleme raporlarında kullanılan temel sonuçlara ulaşılmıştır.

\section{LiTERATÜR INCELEMESi}

Gayrimenkul değerlemesine, muhasebe standartlarına birçok literatüre rastlanmıştır ancak gayrimenkul değerlemesinde kullanılan Uluslararası Değerleme Standartları ile ilgili çok az literatüre rastlanmıştır. Yapılmış çalışmalar çoğunlukla UDS ve UFRS açısından değerlemeyi ayrı olarak incelemişler fakat aralarındaki ilişkiler açısından çok nadir olarak çalışma yapıldığı, iki ayrı meslek disiplini çerçevesinde incelemelerin birbirinden ilişkisiz olarak yapıldığı gözlemlenmiştir. Finansal tablolar açısından sadece değerleme raporlarındaki bilgilerin gerekli olduğu zaman kullanıldığı fakat değerleme yöntemleri açısından ilgilenilmediği gözlemlenmiş, literatür taraması sonucu UDS kaynaklarının yetersiz olduğu anlaşılmışır. Muhasebe ve değerleme ile ilgili literatür taramalarında örnekleme yöntemi ile yapılan araştırmalarda, Çil Koçyiğit (2013) çalışmasında borsada işlem gören halka açık şirketlerin finansal tablo dipnotlarını incelemiştir. Yatırım amaçlı gayrimenkullerin gerçeğe uygun değerlerinin, değerleme uzmanı tarafından belirlendiğini belirten işletmeler yaklaşık olarak \%75 iken, bir değerleme uzmanı tarafından değerlemeyen işletmelerin oranın ise \%25 olduğu bulunmuştur. Yatırım amaçı gayrimenkullerini, gerçeğe uygun değer yöntemi ile değerleyen işletmelerde ise gayrimenkul değerlerinin, değerleme uzmanı tarafından belirlendiği belirtilmiştir. Çına Bal (2015) çalışmasında ise Borsa İstanbul’ da işlem görüp, halka açık olan gayrimenkul yatırım ortaklıklarına ait finansal tabloları incelenmiştir. İşletmelerin \%35' i yatıım amaçlı gayrimenkullerini alım sonrası maliyet bedeliyle değerlediği, \%65' inin ise gerçeğe uygun değer yöntemini seçip değerlediği bulunmuştur. Çoğunlukla gayrimenkullerin alımdan sonraki değerlemelerinde pazar değeri yani emsal karşılaştırma değeri seçilmiş olduğu, maliyet yaklaşımı ile değerlemenin ise daha az seçilip kullanıldığı saptanmıştır. Değerleme sorunları ile ilgili literatür çalışmalarında, Köktürk (2009) çalışmasında taşınmaz değerleme konusunu incelemiş ve uygulamadaki normalden sapmaları ve değerlemedeki yönelimleri incelemiştir. Taşınmaz değerlemesindeki sorunları ve çözüm önerilerinin neler olduğunu, alınması gerekli önlemlerin neler olduğunu açıklamış, değerleme mesleğinin sorunlarını değerlendirmiştir. Yomralıoğlu ve Nişancı, (2011) çalışmasında Dünya' da ve Türkiye' de taşınmaz değerlemesi konusunu incelemişler ve çalışmalarında uygulamadaki sorunların neler olduğu, değerleme işleminin altyapısını ele almışlardır. Değerlemedeki yöntemleri, teknikleri inceleyip değerlendirmelerde bulunmuşlardır.

Muhasebe, vergi, iş hayatıyla ilgili mevzuat açısından yapılan literatür çalışmalarına çok sık olarak rastlanmıştır. Akbulut (2011) çalışmasında VUK, UFRS ve Ticaret Kanunu arasındaki ilişkileri ve farkları inceleyip VUK açısından ayrıntılı olarak değerlendirmelerde bulunmuştur. Demir (2017) İnşaat ve gayrimenkul muhasebesi çalışmasıyla gayrimenkullerin muhasebelerini inceleyip örneklerle anlatmış ve UDS, UFRS ve VUK açısından işlemleri değerlendirmiştir. Erer ve Hazır (2014) TFRS' ye göre yatırım amaçılı gayrimenkullerin ölçülmesi ve muhasebeleştirilmesi konusunu ve ilgili muhasebe standartlarını örneklendirerek incelemişler, gerçeğe uygun değer ve maliyet yönteminin kullanılmasını değerlendirmişlerdir. Şengel ve Ağca (2013) İnşaat ve gayrimenkul muhasebesi konularını açıklamışlar, çeşitli örnekler sunmuşlar, konuyu VUK açısından ve UDS açısından incelemişlerdir. Önal (2008) ' deki çalışmasında gayrimenkul değerleme ve önemini vurgulamış, vergisel açıdan değerlendirmelerde bulunmuştur. Değerleme ile ilgili olup muhasebe konularına değinmeyen kaynaklara da çokça rastlanılmıştır. Hacıköylü (2013) emlak finans ve emlak değerleme konularını inceleyip araştırmış, gayrimenkul değerleme raporlama süreçleri ve UDS' ler hakkında bilgiler vermiştir. Hazar (2013) varlık değerleme yaklaşımları çerçevesinde gayrimenkul değerleme çalışmasıyla değerleme kavramlarını açıklamış değerleme işlemleri ve yöntemleri hakkında açıklamalarda bulunmuştur. Hepşen (2015) gayrimenkul değerleme esasları hakkında bilgiler vermiş uygulamalar konusunda örneklerle değerleme işleminin yöntem ve kavramlarını açıklamıştır. Katipoğlu (2007) çalışmasında değerleme yöntem ve kavramlarını açıklayıp, konu ile ilgili değerlendirmelerde bulunmuştur. Tanrıvermiş (2016) gayrimenkul değerleme esasları çalışması ile değerleme mesleğinin kurallarını, değerle yöntemlerini örneklerle uygulamaya yönelik 
olarak açıklamış, UDS ilişkilerini ve ilgili mevzuatı incelemiştir. Utkucu (2007) çalışmasında değerleme ve ilgili mevzuat hakkında değerlendirmelerde bulunmuştur. Yetgin (2009) çalışmasında örnek uygulamalar vererek gayrimenkul değerleme işlemlerini ve değerleme ile ilgili kavramları açıklamıştır.

\subsection{Değerleme Tanımları ve Amaçları}

Değer, gerçekleşmemiş bir veridir, el değiştirmede varlık ve üzerindeki haklar için ödenecek olası fiyattır (UDS, 2017, 10). Değer, değerleme yapılanın özelliklerinden başka ihtiyaçların o andaki şiddetine göre de değişiklik gösterir (Önal, 2008, 24). Değerleme sistematik bir süreç gerektiren bir değer takdiri olup araştırma ve analiz yapılması gereken zihinsel ve fiziksel bir faaliyettir (Katipoğlu, 2007, 197). Gayrimenkul arazi ve arazinin parçası olan olgular, araziye bağlı olan bina, tesisat, toprak altında bulunan tesisat, madenler gibi eklentileri kapsar, gayrimenkule bağlı haklar ve borçlar ise ekonomik olarak fayda sağlar veya yükümlülükler doğurur (UDS, 2017, 5). Gayrimenkul değerlemesi, bir gayrimenkulün, gayrimenkul projesinin veya gayrimenkulle ilgili hak ve faydaların, değerleme gününde tahmini değerinin bağımsız ve tarafsız olarak, objektif ölçütler kullanarak farklı yöntemlerle, tahmin edilmesidir (Yetgin, 2009, 44). Taşınmazın bulunduğu yerin kentsel ya da kırsal yerde olması durumu, bitki örtüsü, iklimi, alt yapısı, ekonomik yapısı, ulaşım, gürültü, manzara durumu gibi özellikleri de gayrimenkulün değerini belirlemede önemlidir (Utkucu, 2007, 114). Gayrimenkulün değerini etkileyen faktörler, imar durumu, konumu, inşaat ve zemin yapısı, parsel şekli, geliri ve ulaşım durumu gibi özelliklerdir (Tanrıvermiş, 2016, 16). Ülkemizde, Uluslararası Değerleme Standartlarının ve Uluslararası Muhasebe Standartlarının kabul edilip yürürlüğe konulması ile çeşitli sektörlerde değerleme gereklilik haline gelmiştir (Afşar, 2013, 130). Gayrimenkul değerlemesi, gayrimenkulün gerçeğe uygun değeriyle düzenlenen finansal tablolara yansıtılması amacıyla yapılırlar (Demir, 2017, 184). Değerleme, finans piyasalarında düzenlenen tabloların hazırlanması, yasal düzenlemelere uyum sağlanması için kullanılır. (UDS, 2017, 1). VUK madde 258' de değerlemenin, vergi matrahlarının hesaplanabilmesi, ekonomik değerlerin takdiri ve tespiti için yapılan bir işlem olduğu açıklanmıştır (Şengel, 2013, 167). Gayrimenkul değerlemesi satış veya kiraya verme işlemi durumunda, şirket birleşme, devirlerinde işletmenin aktifindeki gayrimenkullerin değerlerinin belirlenmesi, gayrimenkul karşılığında teminat altına alınan uzun vadeli kredi gibi amaçlarla yapılabilmektedir (UDS300, 2017, 99). Ayrıca gayrimenkul değerlemesi mahkemelerde, vergi amaçlı olarak, yatırım danışmanlığı için, işletmelerin bazı kararları vermeleri için ticari olan birçok işlemde kullanılmaktadır (Hacıköylü, 2013, 85).

\subsection{Gayrimenkul Değerlemesi Süreçleri ve Raporları}

Gayrimenkul değerlemesinin hangi amaçla yapılacağı, veri toplama ve raporlama aşamalarını da etkiler (Afşar, 2013, 164). Değerleme raporu açık ve yanıltıcı olmayacak bir şekilde sunulmalıdır. Kullanıcıların raporu daha iyi anlamaları için yeteri kadar bilgi olmalıdır. Değerlemeyi doğrudan etkileyen kısıtlayıcı bir durum varsa açık ve doğru bir biçimde bildirilmelidir. Rapordaki sonuç, değerleme uzmanının kanaatidir ve değerlemenin son adımıdır (Hazar, 2013, 121). Değerleme işlemleri, belli bir tarihte, dünyada kabul görmüş teknik ve incelemelerin kullanılarak, kullanım, fayda, gelir ve pazar koşullarını dikkate alarak yapılması gerekmektedir, değerleme yapacak kişilerin deneyim ve bilgi sahibi olması ve en az hata ile raporun gerçekleşmesi gerekir (Hazar, 2013, 112). Değerleme süreci, değerleme uzmanının müşterisinin gayrimenkulünün değeri hakkındaki sorduğu sorulara cevap verebilmek için uyguladığı sistematik yöntem olup bu süreçte izlenecek adımlar kendine özgü aşamalarla tamamlanmakta ve Uluslararası Değerleme Standartları ayrıntılı bir şekilde ele alınmaktadır (Hepşen, 2014, 15). Gayrimenkul değerleme sürecinde ilk olarak değerlemeyi kullanacak olanlar ile kullanım amacı belirlenip değerleme sorununun açık bir şekilde ifade edilmesi ile başlayan ve belirlenen değerin raporlanması ile son bulan bir süreçtir. Kullanım amacından sonra, gayrimenkulün tanımlaması yapılıp, değerleme için veriler toplanır, sosyal ekonomik ve politik etkenler ile gayrimenkulün çevre faktörleri incelenir. Gayrimenkule ilişkin fiziksel özellikleri içeren inşaat kalitesi, malzeme özellikleri, gayrimenkulün içindeki pazarın niteliği unsurları gibi özel veriler incelenir. Son aşamada, gayrimenkulün gelecekteki ve değerleme anındaki durumuna bakılarak gayrimenkul değerleme uzmanı tarafından analiz edilir, rekabete yönelik arz ve talep belirlenir, gayrimenkule ilişkin analizler yapılarak değerleme yöntemleri seçilerek, seçilen değerleme yöntemlerine göre gayrimenkulün değeri belirlenir. Son aşamada ise gayrimenkule ilişkin değer raporlanır. (Hacıköylü, 84, 2013)

Tablo 1: Değerleme Raporlarında Yaygın Olarak Kullanılan Format

\begin{tabular}{|l|}
\hline 1 Rapor Bilgileri \\
\hline 2 Şirket ve Müşteriyi Tanıtııı Bilgiler \\
\hline 3 Değer Tanımı ve Geçerlilik Koşulları \\
\hline 4 Uygunluk Beyanı \\
\hline $\begin{array}{l}\text { 5 Taşınmazın Hukuki Tanımı ve Yapılan İncelemeler (Mülkiyet, Tapu kütüğü ve İmar durumu incelemesi, Son üç yılda } \\
\text { mülkiyet ve imar değişiklikleri ) }\end{array}$ \\
\hline 6 Taşınmazın Lokasyon Bilgisi ve Fiziki Durumu \\
\hline 7 Pazar Bilgilerine ilişskin Analizler \\
\hline 8 Değerleme Süreci (Değerleme yöntemleri, Taşınmazın değerlemesinde kullanılan yöntemler) \\
\hline 9 Taşınmazın Pazar Değerinin Tespiti \\
\hline
\end{tabular}


10 Taşınmazın Kira Değerinin Tespiti

11 onuç

Gayrimenkul değerleme raporu; değerleme ile ilgili bilgiler, değerlemenin amacı, değerleme ile ulaşılmak istenen amaç, kullanılan yöntemler, yapılan analizlerin sonuçları, kullanılan formül açıklamaları, değerlemeyi talep eden kişi veya kuruluşa ait tanıtıı bilgiler, taşınmaz hakkında bilgiler, değerleme ile ulaşılan sonuçların yer aldığı bölüm ve rapor ekleri vardır (Hacıköylü, 2013, 200). Genelde raporlarındaki bilgilerin seçimi değerleme şirketlerine göre farklılıklar göstermekte olup değerleme amacına ve cinsine göre değişebilmektedir. Değerlemedeki süreçler değişik çalışma aşamalarından oluşur. Tablo 1' de değerleme raporunun yapısı verilmiş olup her değerleme şirketine göre bu yapı değişebilmektedir.

\subsection{Uluslararası Değerleme Standartları Komite ve Birlikleri}

Uluslararası değerleme standartları kısa adı IVSC olan Uluslararası Değerleme Standartları Komitesince, bütün dünyadaki değerleme uygulamaları ve Uluslararası Muhasebe Standartları Komitesi ve Uluslararası Muhasebeciler Federasyonu gibi diğer standartlar kurumlarıyla etkiler incelenerek geliştirilmektedir (Afşar, 2013, 188). Uluslararası Değerleme Standartları Komitesi tüm dünyada profesyonel değerleme kuruluşlarını kapsayan, düzenleyen birbirine bağlayan elliden fazla ülkeden çeşitli kurumların üye olduğu uluslararası bir kuruluştur olup değerleme ile ilgili kavramlar ve yöntemler ile ilgili uluslararası değerleme standartlarını düzenlemekten, gözden geçirilmesinden ve üye ülke kuruluşları arasındaki işbirliğinin artırılmasından sorumludur (Hacıköylü, 2013, 197). Dünyada gayrimenkul değerleme standartlarını düzenleyen farklı ülkelerde örgütlenmiş, değişik birlikler ve değerleme komiteleri vardır, SPK tarafından yapılan düzenlemelerde, Uluslararası Değerleme Standartları Komitesince yapılan düzenlemelere uyulması kabul edilmiştir.

\subsection{Gayrimenkul Değerlemesi Düzenlemeleri}

Gayrimenkul değerlemesi; işletmelere sermaye olarak konulan gayrimenkullere, satın alınan ya da kiralanan gayrimenkullere, muhasebe standartlarına göre değer tespitlerinin yapılması gerekliliği nedeniyle, işletme gayrimenkul portföyünün işletilmesi amacıyla, atıl durumdakilerin projelendirilmesi için, SPK, Bankacılık Mevzuatı ve Türk Ticaret Kanunu sebebiyle yapılan finansal düzenlemelerin gerektirdiği için değerleme yapılabilmektedir (Afşar, 2013, 164). Ülkemizde gayrimenkullerde, uluslararası değerleme standartlarının kabulü ile değerleme işlemleri daha sağlıklı olarak yapılmaya başlanmıştır aynı zamanda uluslararası işlemlerde şeffaflık, uyum ve paralellik sağlanmış, gayrimenkul piyasalarının gelişimine katkıda bulunulmuş, ipotek karşıı̆ında verilen gayrimenkul teminatlı krediler için yapılan değerlemelerin güvenilirliğinin arttırılıp finansal raporların daha gerçekçi olması sağlanmıştır (Hacıköylü, 2013, 191). Yasal düzenlemeler, taşınmazın kullanım ve ekonomik değerini dolaylı ya da doğrudan etkileyen etken olup değerleme yapılan taşınmazın içinde bulunduğu bölgeyi ilgilendiren yasal düzenlemeler, özellikle imarla ilgili konuların incelenmesi, taşınmazın hangi imar planı içinde yer aldığının belirlenmesi gerekmektedir. (Utkucu, 2007, 114). Gayrimenkulün serbest bölgede, organize sanayi bölgesinde, yeşil alan sınırları içinde ya da yakınında olması, taşınmazın değerini, yapı izin durumu gibi durumları belirleyen etken olacaktır.

\subsubsection{SPK' da Gayrimenkul Değerlemesi Düzenlemeleri}

62.1 sayılı Sermaye Piyasasında Değerleme Standartları Hakkında Tebliğe göre SPK mevzuatına tabi olarak yaptırılacak değerleme faaliyetlerinde Uluslararası Değerleme Standartlarına uyulması zorunluluğu getirilmiştir, bu standartların uyumlu olmadığı durumlarda öncelikle diğer SPK mevzuatlarına uyulacaktır. Sermaye Piyasası Kanunun 38 maddesinde değerleme esasları düzenlenmiştir. Sermaye Piyasası Kurulunun yetkisi sadece SPK mevzuatına göre yapılan değerlemeler için geçerli olduğundan bu kapsamda yapılmayan değerleme işlemleri için SPK düzenlemelerinin geçerliliği olmayacaktır. 35 sayılı Sermaye Piyasası Mevzuatına göre gayrimenkul değerleme hizmeti verecek şirketler ve bu şirketlerin listeye alınmaları esasları düzenlenmiştir. Değerleme raporları, değerleme uzmanları tarafından, bağımsız ve tarafsız olarak piyasa ve çevreyi dikkate alarak, uluslararası değerleme standartlarına uyularak hazırlanacaktır. Sermaye Piyasasında Muhasebe Standartları Hakkındaki 25 sayılı tebliğe göre yatırım amaçlı gayrimenkullerin makul değer tespiti için yetkilendirilmiş, bağımsız değerleme şirketlerinden değerleme hizmetleri alabilirler. SPK mevzuatına tabi olan işletmeler, yatırım amaçlı gayrimenkullerini rayiç değer ile değerlemesi gerektiği belirtilmiştir. Değerlemenin bağımsız bir şirkete yaptırılacaksa SPK listesinde olan şirketlerden hizmet alınması zorunluluğu getirilmiştir. 52 no' lu Gayrimenkul Yatırım Fonlarına İlişkin Esaslar Tebliğine göre Fonlarda değerleme gerektiren işlemler için işleme konu olan varlıkların, hakların ve kira bedellerinin rayiç değerlerinin tespitlerinin gayrimenkul değerleme kuruluşlarına yaptırılması gerekmektedir. Fon portföyüne alımlar veya satışlar ve kiralamalar tespit edilen değerlemelere göre gerçekleştirilir.

\subsubsection{VUK' da Gayrimenkul Değerlemesi Düzenlemeleri}

Vergi Usul Kanununun 274. maddesinde değerlemede maliyet bedeline göre yapılacağı belirlenmiştir. İşletme tarafından bizzat yapılan satın alma maliyet unsurları; satın alma bedeli, alımla ilgili sigorta giderleri, alış komisyonları, finansman 
giderleri gibi giderlerdir. Alım satım amaçı gayrimenkullerde satış bedelinden, ilan, reklam, komisyon gibi giderler düşüldüğünde net gerçekleşebilir değer bulunabilir. Kullanım amaçlı gayrimenkuller elde etme maliyeti ile değerlenirler, satın alma bedeline, alışta katlanılan giderler, vergiler, resim ve harçlar, finansman giderleri, tadilatlar eklenebilir. Kullanım için alınan yeterli donanım, altyapı, iç mimari özelliklere sahip olmayan gayrimenkuller, işletmenin amaçlarına uygun hale gelene kadar yapılan harcamalar gayrimenkul hesabına aktarılıp muhasebeleştirilir. (Demir, 2017, 144)

\subsection{Uluslar arası Değerleme Standartları}

Uluslararası Değerleme Standartlarında, değerleme metotları belirlenmesi ile ilgili kavramlar açıklanmış, değerleme mesleği ile ilgili temel kavramlar saptanmış, Uluslararası Muhasebe Standartları ile ilgili ilkeler açıklanmış, değerleme standartları ile ilgili genel bir çerçeve çizilerek ulusal düzenlemelerde rehber niteliği taşıması amaçlanmıştır. (Hacıköylü, 2013, 200) Gayrimenkul değerleme raporları değerleme amaçlarına göre ve değerlenen taşınmazın cinsine göre bu ilkelere uyularak hazırlanır. Tablo 2' de UDS yapısı verilmiştir, standartlar genel, varlık standartları ve değerleme uygulamalarında oluşmaktadır. Uluslararası değerleme standartlarının uygulanmasının amacı, değerleme uzmanının yetki ve sorumluluklarının belirlenmesi ve değerleme raporlarında belirli bir standardın sağlanarak, değerleme alanında, uluslararası geçerli ortak bir dilin ve anlayış birliğinin sağlanmasına çalışılmıştır. Sermaye piyasası mevzuatına göre yapılan gayrimenkul değerlemesinin uluslararası standartlara bağlanmasıyla, değerlemenin tarafsızlığı ve bağımsızlığının sağlanması açısından çok önemlidir. Gayrimenkul değerinin belirlenmesine ilişkin uluslararası standartların oluşturulmasıyla, değerlemeyi yapacakların taşıması gereken nitelikler ve değerleme raporunun özellikleri düzenlenmiştir. (Afşar, 2013, 187)

Tablo 2: Uluslar arası Değerleme Standartlarındaki Yapı

\begin{tabular}{|l|l|}
\hline Grup & Uluslar arası Değerleme Standartları \\
\hline \multirow{3}{*}{ çerçeve } & Uluslararası Değerleme Standartları Tanımları \\
\hline \multirow{5}{*}{ Genel Standartlar } & Uluslararası Değerleme Standartları Çerçevesi \\
\cline { 2 - 2 } & UDS 101 İşin Kapsamı \\
\cline { 2 - 2 } & UDS 102 Uygulama \\
\cline { 2 - 2 } & UDS 103 Raporlama \\
\cline { 2 - 2 } & UDS 200 İşletmeler ve Iş̧letmedeki Paylar \\
\cline { 2 - 2 } & UDS 210 Maddi Olmayan Varlıklar \\
\cline { 2 - 2 } & UDS 220 Tesis ve Ekipman \\
\cline { 2 - 2 } & UDS 230 Taşınmaz Mülkiyet Hakları \\
\cline { 2 - 2 } & UDS 233 İnşaat Halindeki Yatırım Amaçlı Gayrimenkuller \\
\cline { 2 - 2 } & UDS 250 Finansal Araçlar \\
\hline Değerleme Uygulamaları & UDS 300 Finansal Raporlama Amaçlı Değerleme, \\
\cline { 2 - 2 } & UDS 310 Teminatlı Borçlanma İşlem Taşınmaz Mülkiyet Hakları Değerlemesi. \\
\hline
\end{tabular}

\subsection{UDS' ye Göre Gayrimenkul Değerleme Yöntemleri}

Değerleme yönteminin seçimi, değerleme yapılacak nesneye ve değerlemenin amacına bağlıdır. Kabul gören normlaştırılmış değerleme yöntemleri; satışların karşılaştırılması yöntemi, maliyet yöntemi, gelir yöntemi gibi yöntemlerdir. Genelde bu üç yöntemden hangilerinin uygulanacağına karar verilmesi gerekmektedir. Doğru yöntemlerin seçilmesi, doğru rayiç değerin saptanması açısından çok önemlidir. Hangi yöntemin kullanılacağının son kararı, kullanılan tüm verilere bakılarak, süreçler hesaba katılarak karar verilir. (Afşar, 2013, 130). Değerlenen varlıkların cazibelerini yitirmeleri, eskiyip yıpranmaları ya da demode olmaları nedeniyle, yeniden yapılabilecek ya da satın alınabileceklerden değerleri daha düşük olacağından değerleri belirlenirken, kullanılan değerleme yöntemine göre düzeltme yapılması gerekmektedir (UDS, 2017, 23). Değerleme raporları finansal piyasalarda ve diğer birçok piyasalarda çeşitli amaçlar için kullanılmaktadır olup finansal tabloların hazırlanmasında, teminat karşılığı borçlanmalarda, yasal düzenlemelere uyum sebebiyle kullanıldıklarından değerlemenin doğru bir şekilde yapılıp, o taşınmaza ilişkin özelliklerin hesaplanması ve değerlemeye yansıtılması gereklidir.

\subsubsection{Pazar Değeri, Emsal Karşılaştırma Yöntemi}

Pazar değeri, bir mülkün istekli alıcılarla satıcılar arasında herhangi bir ilişkiden etkilenmeden, zorlama olmadan konu hakkında yeterli bilgi sahibi, basiretli kişiler arasında, uygun bir pazarlamanın ardından değerleme tarihindeki alım satım işleminde el değiştirmesi durumunda takdir edilen tutardır. (Hazar, 2013, 206) Pazar yaklaşımında değer, değerleme yapılacak varlıkla fiyat bilgisi mevcut olan varlıklarla karşılaştırmalı olarak belirlenir. Yeterli sayıda işlem varsa ve bu bilgiler geçerliyse benzer veya aynı varlıklara ait işlem gören, teklif verilen fiyatlar işleme alınabilir. Değerlemesi yapılacak varlık ile pazarda işlem gören varlıklar arasında yasal olarak, ekonomik veya fiziksel özellik olarak farklılıklar olabilir, pazardaki işlemlerden sağlanan fiyat bilgilerinde düzeltme yapmak gerekebilir. (UDS, 2017, 24). Satışların karşılaştırılması ya da emsal piyasa yaklaşımında değerleme uzmanı, mülkü benzer olan ve yakın bir zamanda satılmış olan mülklerle karşılaştırarak bir 
değer takdiri yapar. Uygun karşılaştırma kriterleri oluşturulup, seçilen karşılaştırma kriterlerine göre, gerekli düzeltmeler yapılarak mülkün değeri belirlenir. Piyasada yeterli ve güvenilir verinin bulunması durumunda her tür gayrimenkule uygulanır ve kullanılan en uygun yöntemdir. Satışın gerçekleştiği dönemden güncel değerleme gününe kadar olan piyasadaki gelişmeler dikkate alındığı için günümüzde en çok kullanılan yöntemdir. (Yetgin, 2009, 57). Piyasa değerine göre firmalarda, büyük miktarlarda gayrimenkul yatırımları yapılmakta ve ipotek kredileri verilmektedir. Uluslararası Değerleme Standartları Komitesi' ne göre piyasa değeri, belirli bir tarihteki istekli alıcı ile istekli satıcı arasında etki altında kalınmaksızın ve çıkarlarına göre doğru pazarlama ile alıcı ve satıcının bilgili, ihtiyatı olarak baskı altında olmaksızın satışı gerçekleştirebilecekleri tahmini tutardır. Tahmin edilen tutar, rekabet piyasasında satılabilecek en yüksek fiyattır. (Hacıköylü, 2013, 82)

Örnek: Örnek uygulamada iş hanının değerlemesi istenmektedir. Emsal değerleme yöntemi kullanılacaktır. Düzeltme kriter oranları, çok kötü-çok büyük ise \%20 üzeri, kötü-büyük ise $+\% 11,+\% 20$ arasında, orta kötü-orta büyük ise $+\% 1,+\% 10$ arasında, benzer ise \%0 yani düzeltme yok, orta iyi-orta küçük ise -\%1,-\%10 arasında, iyi-küçük ise -\%11,-\%20, çok iyi-çok küçük ise -\%20 üzeri düzeltme yapılır.

Satılık Emsal Analizi

\begin{tabular}{|c|c|c|c|}
\hline Özellik & Emsal Taşınmaz 1 & Düzeltme Oranı & $+\% 0+\% 5+\% 0-\% 10-\% 5=-\% 10$ \\
\hline Lokasyon İçin Düzeltme & Benzer \%0 & Ortalama m2 satış değeri & $1000 T L$ \\
\hline Fiziksel/İnşaat Özel.Düz. & Orta Kötü \%5 & Düzeltme Tutarı & $-100 T L$ \\
\hline Kullanım Niteliği Düz. & iyi \%15 & Ayarlanmış değer & $900 \mathrm{TL}$ \\
\hline Büyüklük İçin Düzeltme & Orta Küçük -\%10 & \multirow{2}{*}{\multicolumn{2}{|c|}{ Ortalama emsal değer=(Emsal 1+emsal $2 \ldots .+$ emsal 5)/5 }} \\
\hline Pazarlık Payı & Var \%5 & & \\
\hline
\end{tabular}

Taşınmaz değeri arsa ve bina ile birlikte 1.000 metrekaredir. Emsallerden metrekare fiyatının 900TL olduğu bulunmuştur. Emsal karşılaştırma yöntemine göre ve gelir indirgeme yöntemine göre fiyatı bulmak istersek, değer 900.000 TL olarak bulunur.

\begin{tabular}{|l|l|l|}
\hline M2 & Birim Fiyat & Emsal Karşılaştırma Yönteminde Göre Değer \\
\hline $1.000 ~ m 2$ & $900 \mathrm{TL}$ & $1.0 \quad 900=900.000 \mathrm{TL}$ \\
\hline
\end{tabular}

\subsubsection{Değerlemede Maliyet Yaklaşımı}

Maliyet yaklaşımında, yapılı olan bir taşınmazın, değerleme günündeki maliyet bedelinin hesaplanması hedeflenir. Yeniden üretme maliyeti ve yerine koyma maliyeti olarak iki şekilde düşünülebilir (Hazar, 2013, 140). Yeniden inşa maliyeti, var olan bir binanın kendi özellikleriyle aynısını inşa etme maliyetidir. Yerine koyma maliyeti, modern malzeme kullanarak, güncel standartlarda, tasarım ve planlar uygulayarak eşdeğer bir bina inşa etme maliyetidir (Katipoğlu, 2007, 208). Maliyet yöntemine göre gayrimenkul değeri belirlenirken arsanın değerine yapının maliyet değeri ilave edilir, yapının maliyet değeri ise yeniden inşa değerinden yıpranmaların çıkarılması ile elde edilir. (Afşar, 2013, 137) Maliyet yaklaşımı, piyasada sürekli alımı, satımı yapılmayan özel kullanımı olan mülklerin değerlemesinde, karşılaştırılabilir emsal satış bilgisinin olmadığı ya da yetersiz olduğu durumlarda, alışılmışın dışında farklı bir mülk ve gelir getirmeyen bir mülk olduğunda maliyet yaklaşımının kullanılması uygun görülecektir (Hepşen, 2014, 31). Maliyet yaklaşımı genelde diğer değerleme yöntemlerini teyit amacıyla kullanıır, nadiren teyit amacı dışında kullanılır (UDS310, 2017, 118). Maliyet yaklaşımında alıcının, zaman kaybı, risk nedeniyle ya da elverişli olmama gibi etkenler nedeniyle, satın alma ya da yapımla edinilmiş olsun aynı faydayı sağlayan başka bir varlığın değerinden fazla ödeme yapmayacağı ilkesine dayanır. (UDS, 2017, 24) Maliyet yaklaşımının kullanım alanlarından olan emlak vergisi ve kamulaştırma yasalarına göre gayrimenkullerin maliyet yöntemiyle değerlemesi gerekmektedir. (Afşar, 2013, 137). Maliyet yöntemi, otel, fabrika, sanayi sitesi, iş hanı veya geniş bahçeli ev gibi yapılı gayrimenkullerin değerlemesinde kullanılır. Değerleme uzmanları yapının tamamen inşa edilmesinin veya yapının benzerinin yerine konulmasının maliyetini karşılaştırıllar. Karşılaştırma yapılırken yapının yaşı, mevcut olan durumu ve sağladığı imkân farklııkları önemsenir, inşaat veya geliştirme maliyetleriyle ilişkili karşılaştırılabilir veriler miktar, nitelik ve fayda açısından hesaba katılır. (Tanrıvermiş, 2016, 150)

Örnek: Uygulama Mülk Değerleme şirketi verilerinden uyarlanmıştır. Maliyet yöntemine göre değerleme yapılırsa. Arsa bedeli emsal karşılaştırma yöntemine göre belirlenir. Bina maliyeti yapı sınıfına göre resmi maliyet rakamı olan $1000 \mathrm{TL}$ alınmıştır. \%10 eskime payı hesaplanmıştır.

\begin{tabular}{|l|c|c|c|}
\hline Cinsi & m2 & Birim Değer & Değer \\
\hline Arsa Değeri & 1000 & 500 & $500.000 T L$ \\
\hline Taşınmaz Değeri (\%10 yıpranma kabulü ile 1000*0.90) & 500 & 900 & 450.000TL \\
\hline Şerefiye Değeri & & & $100.000 T L$ \\
\hline
\end{tabular}




\begin{tabular}{|l|l|l|l|}
\hline Maliyet Yöntemine Göre Değer & & & $1.050 .000 T L$ \\
\hline
\end{tabular}

\subsubsection{Değerlemede Gelir Yaklaşımı Yönteminin Kullanımı}

Gelir Yaklaşımında, gelecekteki nakit akışları hesaplanarak, bir varlığın yararlı ömrü boyunca yaratacağı gelirler dikkate alınır, gelirler uygun indirgeme oranları belirlenerek hesaplanır (UDS, 2017, 23). Gelir yaklaşımında gayrimenkulün ekonomik kullanım ömrünün belirlenmesi gerekir (Hacıköylü, 84, 2013). Gelir indirgeme yöntemindeki hesaplama taşınmazın, gelecekteki üreteceği vergi hariç kira gibi nakit girişlerinin bugünkü değerlerine göre hesaplanan uzun dönemli bir tahmin yöntemidir. Ekonominin, sektörün ve projedeki risk seviyesine göre ıskonto oranı ile bugüne indirgenerek, gayrimenkulün doluluk oranı, kira geliri gibi faktörler göz önünde bulundurularak değeri hesaplanır. Gelir indirgeme ya da kapitalizasyon oranı yöntemi, güvenilir karşılaştırma verilerinin olmadı̆̆ı, gelir getiren taşınmazların değerlendirilmesinde kullanılır. Taşınmazın gelecekte getireceği gelirler tespit edilebiliyorsa en iyi yaklaşımlardandır. Gayrimenkulün değerlemesinde net gelir kullanılır, brüt gelirden boşluk, toplama kaybı ve işletme giderlerinin çıkarılması ile gayrimenkulün net geliri bulunur. Binanın eski olduğu ve bu sebeple maliyet yöntemini kullanmanın güvensiz olacağı taşınmazların değerlemesinde gelir indirgeme yöntemi kullanılabilir. (Yetgin, 2009, 58). Direkt kapitalizasyon yönteminde gayrimenkulün değeri, yıllık net işletme gelirinin kapitalizasyon oranına bölünmesi ile hesaplanır. Efektif brüt gelirin hesaplanmasında, toplam brüt gelirden boşluk ve kira kayıplarının düşülmesi gerekmektedir. Boşluk oranlarının ve kira kayıplarının piyasa şartlarına göre belirlenmesi gereklidir. Oranların hesaplanmasında, gayrimenkulün geçmiş dönemlerdeki kira kayıplarının ve boşluk oranları belirlenir. Gayrimenkulün bulunduğu bölgedeki doluluk oranları, kira kayıpları, ortalama kira süreleri, kiracıların özellikleri ve kaliteleri, gelecekte oluşması muhtemel ekonomik değişimlerin de dikkate alınması gerekmektedir. Faaliyet giderleri, bir gayrimenkulden beklenen efektif brüt geliri sağlamak amacıyla yapılması gereken sürekli harcamalardır, net faaliyet geliri ise gayrimenkulün efektif brüt gelirinden yapılan faaliyet giderlerinin düşülmesi ile bulunur. (Afşar, 2013, 139)

Örnek: Kira değeri analizinde bölgedeki piyasa verilerine göre taşınmazın benzerlerinin kiraları 6.000 TL olduğu anlaşılmıştır. Bölgedeki diğer taşınmazların brüt kira çarpanı 15 yıl ise gayrimenkulün yıllık brüt getirisi 72000 olarak bulunur. Gayrimenkulün getirisi 1.080.000 TL olarak bulunur.

Brüt Kira Çarpanı = Gayrimenkul Değeri / Yıllık Brüt Gelir ve Kapitalizasyon Oranı = Yıllık Net Gelir / Gayrimenkul Değeri

\begin{tabular}{|l|l|l|l|l|}
\hline Aylık Kira & Yıllık Kira & Bölge Brüt Kira Çarpanı & Taş. Değeri & Kapitalizasyon Oranı \\
\hline $6.000 \mathrm{TL}$ & $6.000 * 12=72.000 \mathrm{TL}$ & $15 \mathrm{yıl}$ & $1.080 .000 \mathrm{TL}$ & $72.000 / 1.080 .000=0,066$ \\
\hline
\end{tabular}

Örnek: Taşınmaz sahibine ait banka şubesi olarak kullanılmaktadır. Kira tutarı bilinmemektedir. Taşınmazın bulunduğu konumdaki binaların kira bedelleri incelenmiş ve kira aylık kira bedelinin metrekare fiyatının 50 TL olabileceği saptanmıştır. Değerleme yapılan taşınmazın niteliği ve kullanım amacı nedeniyle direkt indirgeme yaklaşımı kullanılacaktır. Yapılan piyasa araştırmasında bölgedeki ticari amaçılı kullanılan gayrimenkuller için brüt kira çarpanı 14 yıl olduğu bulunmuş ve taşınmazın muhtemel değeri hesaplanmıştır.

Brüt Kira Çarpanı = Gayrimenkul Değeri / Yıllık Brüt Gelir formülünden

\begin{tabular}{|l|l|l|l|l|l|}
\hline m2 & Böl.Ay.m2 Kira & Aylık Kira & Yıllık Kira & Böl.B.Kira Çar. & Taş.Değeri \\
\hline 1000 & 50 & $50 * 1000=50000 \mathrm{TL}$ & $50000 * 12=600000 \mathrm{TL}$ & 14 yıl & $8.400 .000 \mathrm{TL}$ \\
\hline
\end{tabular}

Örnek: Taşınmaz değeri, çevredeki benzer binaların kapitilizasyon oranı uygulanarak bulunur. Yıllık kira tutarından, gayrimenkulün değeri Nakit Gelir Akımları Yöntemine göre bulunacaktır.

Brüt Kira Çarpanı = Gayrimenkul Değeri / Yıllık Brüt Gelir

Kapitalizasyon oranı = Yıllık Net Gelir / Gayrimenkul Değeri formülünden hesaplanır.

\begin{tabular}{|l|l|l|l|}
\hline Aylık Kira & Yıllık Kira & Bölgedeki Kapitalizasyon Oranı & Değer \\
\hline $20.000 T L$ & $12 * 20.000=240.000 T L$ & $\% 5$ & $240.000 / 0,05=4.800 .000 T L$ \\
\hline
\end{tabular}

\subsubsection{Etkin ve Verimli Kullanım Yaklaşımı}

En etkili ve verimli değerleme yöntemi, en yüksek net geliri gösteren bir kullanım türü olup değerleme uzmanı zamanının büyük kısmını en uygun kullanımı bulmaya çalışır (Katipoğlu, 2007, 201). Bir mülkün, belli bir kullanıcı için, belirli bir kullanıma yönelik sahip olduğu değeri olup pazarla bir ilişkisi yoktur, mülkün en verimli ve en iyi kullanımına, mülkün sahibi olduğu kuruma yaptığı katkı üzerinde durulur. (Hepşen, 2014, 13) Etkin ve Verimli Kullanım Yaklaşımı değerleme raporlarında nadir kullanılan yöntemlerden olup kullanılabilmesi için gerekli şartların oluşması gerekir, alternatif olarak ta kullanılabilir. UDS 230 Taşınmaz Mülkiyet Hakları standardında temel değerleme yöntemleri olarak pazar, gelir ve maliyet yaklaşımları vardır. Etkin ve verimli kullanımda, taşınmazın fiziki olarak mümkün, finansal olarak gerçekleştirilebilir, yasal olarak izin verilebilen ve mülkü en yüksek değere çıkaran en olası kullanımı tespit edilir. Binalardaki yıpranma ve eskimeler 
dikkate alınarak, arazi için en uygun iyileştirme ve yenileme çalışmaları yapılarak, imar uygulamalarında parsellere en uygun imar hakkının verilmesi gibi alanlardaki değerleme çalışmalarında kullanılır. (Tanrıvermiş, 2016, 31). İşletmelerin geliştirme amaçlı edindikleri gayrimenkullerde değerlemede, halen mevcut ve muhtemel geliştirme izin ve yetkileri değerleme hesabına katıır. Geliştirme amaçlı gayrimenkullerde değerleme yaklaşımı, projenin durumuna, nasıl geliştirildiğine yani ön satış veya kiralama derecesine göre seçilir. Değerleme işleminde tahmini geliştirme süresi belirlenir, projede hedeflenen aşamalar yansıtılır, gerekli olduğunda bugünkü değere indirgeme yapılarak ek maliyetler ile gelirlerin etkileri hesaplanır, pazar eğilimlerinin nasıl olabileceği saptanır, projedeki riskler saptanır, taraflar arasındaki tüm ilişkilerin etkileri hesaplanır. (UDS, 2017, 121)

Örnek: Uygulamada değerleme yapılan iki arsa boştur, geliştirme yöntemi uygulanması durumunda arsanın değeri hesaplanmak istenmektedir. Çözüm olarak arsalarda yapılması varsayılan yasal olarak uygun, finansal açıdan da verimli, ekonomik olan projeler analiz edilecektir. Sektörün durumu, geleceğe yönelik beklentileri de değerlendirilir. Projenin gerçekleşmesi halinde gelir gider tahminleri yapılır, projenin gelir ve giderleri indirgemesi ile net bugünkü değerleri bulunur. Arsalarda biri üzerinde inşaat yapılırsa, imar durumu incelenmiştir. Bölgedeki yaygın yapılaşma koşullarının TAKS 0,15 ve KAKS 0,75 olduğu ve 5 kat yapılaşmaya izin verildiği referans alınarak toplam inşaat alanı hesaplanır. Diğer arsa bölgedeki imar koşullarına göre inşaat yapmaya uygun olmadığı için emsallerinin metrekare değerlerine göre arsanın değeri hesaplanmıştır.

\subsection{VUK, TMS ve UDS' de Amortisman}

UDS' ye göre amortismanlı değer kaybı ille maliyetin belirlenmesi yönteminde amortisman, herhangi bir sebepten taşınmazın değerinde meydana gelen eskime, yıpranma ve kayıplar olup değerleme uzmanı tarafından hesaplanır, ikame ve yeniden inşaat maliyetlerinden çıkarılarak yapının yıpranmış maliyeti hesaplanır (Hazar, 2013, 148). UDS ve TMS' de faydalı ömür benzerlik göstermesine rağmen kullanılan yönteme göre farklılıklar gösterebilmektedir örneğin Azalan Bakiyeler yöntemi TMS' de ve UDS' de bulunmamaktadır (Demir, 2017, 147). TMS' de amaç gayrimenkul gibi varlıklar ve yükümlülüklerin gerçeğe uygun değerleri tespit edilerek işletmenin ekonomik durumunun gerçeğe uygun olarak yansıtılmasını sağlamak olmasına rağmen VUK' ta ise gayrimenkuller işletmeye mal oluş değeri ile muhasebeleştirilirler, işletmeden çıkışları yapılana kadar yeniden değerleme yapılmazlar (Akbulut, 2011, 25). Amortismanda TMS, UDS ve VUK' farklı kavramlar olduğu ve hesaplama yöntemlerinin farklı oldukları görülmektedir. Vergi Usul Kanunu madde 314' e göre, boş arazi ve arsalar amortismana tabi değildir. Tarım işletmelerindeki yetiştirilen meyvelikler gibi tarım tesisleri, inşa edilmiş olan yollar, haklar amortismana tabidir. Vergi Usul Kanunu madde 315' e göre Maliye Bakanlığınca faydalı ömürler dikkate alınarak tespit ve ilan edilen oranlar üzerinden amortisman hesaplanırken TMS' de ise faydalı ömür işletmenin o sabit kıymetten faydalanacağı süre dikkate alınarak, işletmece belirlenir. TMS' de arsalara sınırsız faydalı ömürleri oldukları nedeniyle amortisman uygulanmaz, binalarda ise amortisman, arsa hariç değerlere uygulanır. TMS' de sınırsız yararlı ömre sahip olan kıymetler, amortismanla değil değer düşüklüğü testi ile yok edilir. (Demir, 2017, 146)

\subsection{UDS 300 Finansal Raporlama Amaçlı Değerleme}

Finansal raporların hazırlanırken değerlemelere çeşitli muhasebe amaçları için ihtiyaç duyulmakta olup değerleme gereken muhasebe amaçları; finansal tablolarda yer alacak bir varlık veya yükümlülük değerinin belirlenmesi, satın alınan işletmenin alım bedelinin dağıtılması, değer düşüklüğü testinin yapılabilmesi, varlıkların kiralamalarının sınıflandırılabilmesi, amortisman giderinin hesaplanabilmesi, değerleme girdilerinin belirlenmesidir (UDS300, 2017, 95). Gayrimenkul değerlemelerinin TMS' de varlıkların gerçeğe uygun, piyasa değerlerinin bulunması için değerleme yapılması gerekebilmektedir. UDS 300 Finansal Raporlama Amaçlı Değerleme standardına göre finansal tablolar için yapılan değerlemeler, TMS şartlarına uygun olarak yapılmalıdır. Muhasebe standardında aksi belirtilmedikçe yapılan değerlemelerde Uluslararası Değerleme Standartları ilkeleri kullanılır. UDS 101' e göre değerlemesi yapılacak varlı̆ı̆n ve sağlanacak faydaların tanımlanması, ne amaçla kullanıldı̆̆ı, nasıl sınıflandırıldığı belirtilmelidir. Muhasebeleştirme işlemi varlıkların kullanımına göre veya elde tutulma amacına göre, işletmenin faaliyet türüne göre değişebilmektedir. (UDS300, 2017, 96)

\subsubsection{TFRS, TMS ile UDS Çelişirse}

UDS 300 Finansal Raporlama Amaçlı Değerleme, Genel Kabul Görmüş Değerleme Uygulamalarına göre zorunlu şartlar ileri sürülmez, muhasebeleştirme ile ilgili TFRS hükümlerine uyulması gerekmekte olup eğer TFRS ile UDS arasında çelişkiler olması durumunda TFRS hükümleri geçerli olacaktır (UDS300, 2017, 99). Yapılan değerlemenin, Uluslararası Değerleme Standartları'na uyularak yapıldı̆̆ı değerleme raporunda teyit edilmesi gereklidir, bazen Uluslararası Değerleme Standartlarından sapılması gerektiğinde bu sapmalar gerekçeleri ile birlikte değerleme raporunda açıklanır, bunlar yanıltıcı bir değerlemenin gerekçesi olmamalıdır (UDS 101, 2017, 31). Tablo 3' te UDS ile TMS ve TFRS ilişkileri verilmiştir. UDS incelenip bu ilişkiler bulunmuştur. UDS incelenip içinde muhasebe ve değerleme ile ilişkili olanlar tablo formatında verilmiştir.Değerleme raporlarının, muhasebe gibi diğer standartların uygulanması gerekli ise, Uluslararası Değerleme 
Standartları Komitesi, gayrimenkul değerleme uzmanlarının ilgili muhasebe işlemlerini anlamalarını tavsiye etmektedir. Finansal bilgilendirme raporları veya bir muhasebe işlemi değerlemeye alınacaksa, değerleme uzmanı hem muhasebe standartlarının gereklerini hem de gayrimenkul değerlemesiyle ilgili olan gayrimenkul değerleme standartlarını uygulayacaktır. Eğer uygulanması gereken standartlar birbirleri ile çatışıyorsa, değerleme uzmanı, değerleme raporunda bu durumu açıklaması gerekecektir. (Afşar, 2013, 189)

Tablo 3: Uluslar arası Değerleme Standartları içinde UMS (TMS), UFRS (TFRS) Geçen Standartlar

\begin{tabular}{|l|l|c|}
\hline UDS Standardı & UMS (TMS), UFRS (TFRS) geçenler & TMS, TFRS \\
\hline UIDS Çerçevesi & UFRS genel bilgileri içermektedir & var \\
\hline UDS 300 Finansal & TFRS 13 Gerçeğe Uygun Değer Ölçümü, TFRS 7 Finansal Araçlar, UFRS & var \\
Raporlama Amaçıı & 3işletme Birleşmeleri TMS 16 Maddi Duran Varlıklar, TMS 40 Yatırım amaçlı \\
Değerleme & $\begin{array}{l}\text { gayrimenkuller TMS 36 Varlıklarda Değer Düşüklüğü, TMS 17 Kiralama } \\
\text { İşlemlerinden bahsedilmiş. }\end{array}$ & \\
\hline UDS 310 Teminatlı & Yatıım amaçlı gayrimenkul (TMS 40 Yatırım Amaçlı Gayrimenkuller) & Finansal \\
Borçlanma İşlemlerinde & Sahibi Tarafından Kullanılan Mülk, İşletmeye Özel Mülk, Ticaretle ilişkili Mülk, & tabloları \\
Taşınmaz Mülkiyet & Tükenen Varlıklar (TMS 2 Stok, TMS 16 Mad. Dur. V.) & etkiliyor \\
Hakları Değerlemesi & Geliştirme Amaçı Mülk (TMS 11 İnş.Söz., TMS 16) & \\
Standardı & Satış Amaçlı Gayrimenkullerin Değerlemesi (TFRS5) & Finansal \\
\hline UDS 230 Taşınmaz & Pazar Yaklaşımı (TFRS 13 Gerçeğe Uygun Değer Ölçümü) & tabloları \\
Mülkiyet Hakları & Gelir Yaklaşımı (TMS 39 Fin.Araç.Muh.Ölçme) & \\
Değerleme Yaklaşımları & Maliyet Yaklaşımı (TMS 16 Maddi Duran Varlıklar) & \\
Standardı & &
\end{tabular}

\subsubsection{UDS 300 Finansal Raporlama Amaçlı Değerleme ile TMS Kullanımı}

UDS 300 Finansal Raporlama Amaçlı Değerleme standardına göre TFRS 13' e göre gerçeğe uygun değer kullanılıyorsa kullanılan hiyerarşi seviyesinin finansal tablolarda açıklanması gereklidir. TFRS $13^{\prime}$ te üç farklı hiyerarşi seviyesi var olup birinci seviye düzeltilmemiş olan fiyatlar, ikinci seviye varlıklara veya borçlarla ilgili olan, gözlemlenebilir olan değerleme girdileri, üçüncü seviye varlıklara veya borçlara ilişkin gözlemlenebilir olmayan değerleme girdileridir. UFRS kapsamında finansal tablolarda kullanılması gereken değerleme raporlarında, hiyerarşi seviyelerine göre muhasebe amaçlı sınıflama yapabilmek için kullanılan değerlemelerle ilgili yeterli bilgi olması gerekir. (UDS300, 2017, 101). TFRS 13' e göre gerçeğe uygun değer piyasaya kaynaklı bir ölçüm olduğundan gerçeğe uygun değer ölçümünde amaç gözlemlenebilir piyasa işlemleri mevcut olsun ya da olmasın mevcut piyasa koşullarındaki, piyasa katılımcıları arasında varlığın satışına veya bir borcun devri için ölçüm tarihinde olağan fiyatın tahmin edilebilmesidir (TFRS13, m.2). UDS' deki pazar fiyatına yakın bir tanım olup değerleme tarihinde pazarda el değiştirmede kullanılabilecek tahmini fiyattır. TMS 17 Kiralama İşlemleri Standardına göre kiralamalar faaliyet kiralaması ya da finansal kiralama olarak sınıflandırılırlar. Değerleme işleminde, kiralamanın faaliyet kiralaması mı yoksa finansal kiralama olarak mı sınıflandırılacağı belirlenir, finansal kiralama olarak sınıflandırılmış ise varlığın veya yükümlülüğün defter değerinin saptanması için yapılır (UDS300, 2017, 105). Arsalar, amortismana tabi olmadığı için arsa kiralaması faaliyet kiralaması olarak sınıflandırılması uygundur ancak yatırım amaçlı gayrimenkullerde arsa ve üzerinde bina olan mülkler olduğundan TMS 40 Yatırım Amaçlı Gayrimenkuller Standardına göre kiralama yapılan yatırım amaçlı gayrimenkuller, ilk muhasebeleştirmelerde TMS 17 Kiralama Iş̧lemleri Standardı kapsamında bir finansal kiralama olarak ta kaydedilebilirler (UDS300, 2017, 108). Gayrimenkul değerleme raporları finansal kiralamalarda da kullanılmaktadır. Arsa ve üzerinde yapı veya gayrimenkule ilişkin haklar kiralamaya konu ise bunların muhasebeleştirilmesinde TMS 17 hükümlerine uymak gerekecektir. Bir işletme birleşmesi söz konusu ise TFRS 3 Şirket Birleşmeleri Standardı kapsamında edinilen gayrimenkullerin, gerçeğe uygun değer üzerinden muhasebeleştirilmesi gerekir. İşletmenin devri için ödenen devir parası ile şirketin varlıkları arasındaki farkın şerefiye olarak muhasebeleştirilmesi gerekir (UDS300, 2017, 110). Şirket birleşmelerinde gayrimenkul değerleme raporları yaygın olarak kullanılmakta olup değerleme işlemi sonuçlarına göre muhasebeleştirmede dikkat edilmesi gereken hususlar vardır.

\subsection{UDS 310 Teminatlı Borçlanma İşlemlerinde Taşınmaz Mülkiyet Hakları Değerlemesi}

\subsubsection{Sahibi Tarafından Kullanılan Gayrimenkullerin Değerlemesi}

Mal veya hizmet üretimi, tedariki veya idari amaçla kullanılan gayrimenkuller, sahibi tarafından kullanılan gayrimenkuller olarak sınıflandırılıp, üretim sürecinde diğer varlıklarla bağımlı olarak nakit akışı yaratıklarından "TMS 16 Maddi Duran Varlıklar" standardı kullanılır (TMS 40, m.7). Gayrimenkul değerlemede sahibinin kullandığı gayrimenkuller, borçlanma için teminat gösterilecekse, gayrimenkulün üzerinde kısıtlama olmaksızın alıcıya devredileceği varsayılır fakat UFRS' ye göre değerleme yapılırken işletmenin özel kullanımı değerlemeye katılır, UDS' ye göre ise özel kullanım değerleme raporuna yansıtılmaz, gayrimenkulü kullanan işletme elde edeceği özel faydalar dikkate alınmaz. (UDS310, 2017, 118) 


\subsubsection{Yatırım Amaçlı Gayrimenkullerin UDS ve TMS' ye Göre Değerlemesi}

Yatırım amaçlı gayrimenkuller, işletmeler tarafından kira geliri, değer artış kazancı gibi amaçlarla elde tutulan gayrimenkullerdir, diğer gayrimenkullerden bağımsız olarak nakit akışı yarattıklarından mal veya hizmet üretimi, idari amaç için kullanılan ya da işletmenin faaliyet alanına göre iş akışına göre satılmak üzere işletmenin elinde tuttuğu gayrimenkullerden farklıdır (TMS 40, m.7). Yatırım amaçı gayrimenkullerde ilk maliyet esasına göre aktife kaydedilen gayrimenkullerde sonraki aşamalarda maliyet ya da gerçeğe uygun değer uygulanır (Akbulut, 2010, 84). TMS 40 Yatırım Amaçlı Gayrimenkuller standardına göre işletmeler gerçeğe uygun değer yöntemini kullanıyorlarsa ölçüm amacıyla yatırım amaçlı bulundurdukları gayrimenkullerinin gerçeğe uygun değerlerini hesaplamaları gerekir. Eğer işletmeler maliyet yöntemini kullanıyorlarsa açıklama yapmak için yatırım amaçlı olarak bulundurdukları gayrimenkullerinin gerçeğe uygun değerlerini hesaplamak zorundadırlar. İşletmelerin zorunlu olmamalarına rağmen yatırım amaçlı olarak bulundurdukları gayrimenkullerini, gerçeğe uygun değerlerini konusunda uzman, yetkilendirilmiş, gerekli bilgiye, deneyime sahip bağımsız bir değerleme uzmanı tarafından değerleme yapılması, TMS 40 standardınca önerilir. (TMS 40, m.32). Gayrimenkul değerlemede maliyet yönteminin seçilmesi ya da gerçeğe uygun değer yönteminin seçilmesi finansal tablolardaki değerlerinin değişmesine neden olmaktadır. Gerçeğe uygun değer yöntemi yatırımcı açısından daha piyasa değerine dayanan gelecekteki nakit akışlarını yansıtan fiyatlama yöntemidir. Maliyet yöntemi ise tahakkuk esasına dayanmaktadır. Gerçeğe uygun değer işletmelerin borç ödeyebilme kapasitelerinin anlaşılabilmesi açısından daha fazla bilgi sunabilmektedir. Gerçeğe uygun değerleme yönteminde piyasa odaklı veriler sunduğundan kredi anlaşmaları, teminat karşılı̆ı borçlanmalarda kredi verenlerin daha tercih ettiği yöntemlerdendir. Yatırım amaçlı gayrimenkullerde ilk muhasebeleştirme sonrası yapılan yeniden değerlemelerde gerçeğe uygun değerin ülkemizde daha çok kullanıldığı görülmektedir. (Erer ve Hazır, 2014, 23). TMS 40 madde 56 ya göre ilk muhasebeleştirme işlemi sonrasında maliyet yöntemi seçilmişse tüm yatırım amaçlı gayrimenkullerde TMS 16 'da belirtilen hükümlere göre maliyet yöntemi kullanılır. TMS 16 , madde 30' a göre bir gayrimenkul muhasebeleştirildikten sonra, gayrimenkulün maliyetinden birikmiş amortismanlar ile birikmiş değer düşüklüğü zararları indirilip değer hesaplanır. Firmalar maliyet yöntemini seçmişlerse gayrimenkulün amortisman yöntemini ve faydalı ömrü ile birikmiş amortisman tutarlarının da finansal tablolarda açıklanması gerekir. TMS 40 madde 79' a göre gayrimenkulün gerçeğe uygun değerinin açıklanması, eğer gerçeğe uygun değer ölçülemiyorsa olası değer aralığı açıklanmalıdır. (Erer ve Hazır, 2014, 23)

\subsubsection{Satış Amaçlı Gayrimenkullerin Değerlemesi}

Yakın gelecekte satılmak amacıyla bulundurulan veya inşa edilen, geliştirilme aşamasındaki gayrimenkullerde TMS 2 Stoklar standardı uygulanır (TMS 40, m.9). Satış amaçlı olarak bulundurulan ve sınıflandırma kıstaslarına uyan yatıım amaçlı gayrimenkuller, TFRS $5^{\prime}$ e göre ölçülür (TMS 40, 56). UDS' ye göre değerleme satış amaçlı olursa özel bir değerleme yapılması gerekmez, satış amaçlı Pazar değerini yansıtması işletmenin amaçları ile uyuşacaktır.

\subsection{4. İşletmeye veya Faaliyet Alanına Özgü Özel Mülklerin Değerlemesi}

Özel kullanım amacı ya da işletmeye özgü özel mülkler, biçimi, tasarımı, konumu, benzersizliğinden dolayı değerleme uzmanının kıyaslama yapacağı piyasa bilgileri çok azsa ya da hiç yoksa değerleme işleminin yapılması zorlaşabilir bu durumda değerleme uzmanı, değerleme sonucunun dayanağını oluşturmak ve sonucun anlaşılmasını sağlamak üzere piyasadan veri toplayıp bu verileri geliştirmek, bazı durumlarda maliyetin ve amortismanın hesaplanması gerekebilir (Hazar, 2013, 211). Pazardan ziyade bir mülkün fiziksel, ekonomik, ya da fonksiyonel ilişkisinden kaynaklanan bir değer artışı olduğundan bu değer sadece bu mülkle ilgili özel bir çıkarı olan alıcıya uygulanır (Önal, 2008, 22). UDS 310' a göre gayrimenkuller, işleyen bir işletmenin parçası olduğunda, işletmenin karlıı̆̆ının sürekliliğine bakılması gerekli olabilir. İşletmeye özel mülkün değeri işletmenin faaliyette olup olmamasına göre değişecektir, iki değer arasında ayrımın yapılmış olması gerekir (UDS310, 2017, 120). Değer artışı o işletmeye özgü olmakta olduğundan kapsamlı olarak analiz edilmelidir.

\subsubsection{Geliştirme Amaçlı ve Tükenen Varlıkların Değerlemesi}

Geliştirme amaçlı elde tutulan mülkler veya yapı yapılmasının planlandığı gayrimenkullerin değerlemesinde mevcut olan yapı geliştirme yetkileri, izinleri, ruhsatları, imar planları hesaba katılır. Yapı gelişme planları makul olmalı, pazar katılımcıların beklentilerini, davranışlarını yansıtmalı, tahmini geliştirme süreleri projede hedeflenen aşamaları yansıtmalı ve geliştirme risklerinin saptanması gerekmektedir. Değerleme yaklaşımı mülkün geliştirme durumuna bağlı olarak, projenin ön satış veya kiralama derecesine göre seçilmeli ve projedeki geliştirme ile ilgili ek maliyetlerin ve gelirlerin etkilerinin bugünkü değere indirgenerek hesaplanması gerekmektedir. Proje birden çok bağımsız bölümden oluşuyorsa her bir bağımsız bölümün süresini, satışların gerçekleşme hızlarını açıklayan gerçekçi tahminler değerleme raporunda yer almalıdır. (UDS310, 2017, 120). UDS 310 Teminatlı Borçlanma İşlemlerinde Taşınmaz Mülkiyet Hakları Değerlemesi standardına göre tükenen, zaman içinde değeri azalan varlıklarda özel hususların dikkate alınması gerekli olup, tahmini ömürleri boyunca, değer kaybetme oranları saptanarak değerleme raporunda açıklanması gereklidir (UDS310, 2017, 122). UDS 101 İşin Kapsamı Standardına göre diğer varlıklar ile birlikte kullanılan bir varlık değerleme yapılıyorsa, bunlar arasındaki ilişkiler ve 
değerlemeye etkileri tanımlanmalıdır (UDS 101, 2017, 29). Bağımsız olarak kullanılamadığı için değerleme işleminde kullanılan kısmın hesaplanması gerekecektir.

\subsection{0.Ülkemizdeki Değerleme Raporları}

\subsection{1.Ülkemizdeki Gayrimenkul Değerleme Raporlarının Kullanımı}

Yatırım Amaçlı Gayrimenkulleri için izleyen dönemlerde maliyet yöntemini seçen SPK mevzuatına bağlı bilgi veren işletmelerin, yatırım amaçlı gayrimenkullerinin gerçeğe uygun değerlerini, değerleme uzmanı tarafından belirlendiğini belirten işletmeler yaklaşık olarak \%75 iken, bir değerleme uzmanı tarafından değerlemeyen işletmeler \%25 olmuştur (Çil Koçyiğit, 2013, 265). Yatırım Amaçı Gayrimenkulleri için izleyen dönemlerde gerçeğe uygun değer yöntemi ile değerleyen işletmelerden bilgi veren işletmelerin tümü değerlerinin değerleme uzmanı tarafından belirlendiğini belirtmişlerdir (Çil Koçyiğit, 2013, 267). Borsa İstanbul' da işlem görüp, halka açık olan gayrimenkul yatırım ortaklıklarına ait finansal tablolarının incelenmesi sonucunda \%35 yatııım amaçlı gayrimenkullerini alım sonrası maliyet bedeliyle değerlediği, \%65' inin gerçeğe uygun değer yöntemini seçtiği görülmektedir (Çına Bal, 2015, 412). Çoğunlukla gayrimenkulleri alımdan sonraki değerlemelerde pazar değeri yani emsal karşılaştırma değeri seçilmiş, maliyet yaklaşımı ise daha az seçilmiştir.

\subsection{2.Ülkemizdeki Gayrimenkul Değerleme Problemleri}

Kamu kurumlarında, değerlemesi yapılacak taşınmaza ait belgelere ulaşmada çeşitli sorunlar yaşanmaktadır. Tapu Sicil Müdürlüklerinde ve Belediyelerde farklı uygulamalar olduğu gözlemlenmiştir. Bazı belediyelerde dosya inceleme ücreti alınırken, bazı belediyelerde ücretsiz olarak bu hizmetlerden faydalanılabilmektedir, bazı tapu sicil müdürlüklerinde haftanın belli günlerinde dosya incelemeleri yapılırken bazılarında inceleme problemleri yaşanabilmektedir. (Yomralıoğlu ve Nişancı, 2011, 10). Gayrimenkul değerlemede piyasa koşullarının analizlerinden veri tabanlarının ve endekslerin oluşturulması ve indirgeme oranları gibi değerlerin saptanması, değerleme yöntemlerinden değer oluşturulması açısından çok önemli olduğu halde ülkemizde bu alt yapıların eksikliği bulunmaktadır. Değerleme raporlarındaki zaman kısıtlaması nedeniyle yapılan değerlemelere güvensizlikler oluşmakta, değerleme yöntemlerinin uygulanması açısından yüzeysel uygulamaların çoğalmasına sebep olmaktadır. Ülkemizde gayrimenkul değerleme raporlarının oluşturulmasında etik olmayan davranışlar görülmektedir, bu nedenle etik temellerin daha güçlü hale getirilmesi gerekmektedir. (Köktürk, 2009, 6)

\section{VERI VE YÖNTEM}

\subsection{Bayrimenkul Değerleme Raporları Araştırmasının Amacı}

Bu çalışmanın amacı; ülkemizdeki hazırlanmış gayrimenkul değerleme raporlarının yapılarının nasıl olduğu, kullanılan değerleme yöntemlerinin neler olduğu, kaç adet değerleme yönteminin kullanıldığı, kullanılan değerleme yöntemleri arasında ne kadar fark olduğu yüzdesel olarak bulunmaya çalışımıştır. Aynı zamanda gayrimenkullerin cinslerine göre brüt kira çarpanlarının, kapitalizasyon oranlarının ne olarak hesaplandığı, raporlardaki gayrimenkulün fotoğraflarının olup olmadığına bakarak raporların nasıl hazırlandığı, taşınmazın fiziki olarak incelenip incelenmediğinin saptanması amaçlanmıştır.

\subsection{Araştırmanın Yöntemi ve Sınırları}

Araştırma; Tablo 4' te değerleme raporları bulunan değişik gayrimenkul değerleme şirketlerine ait değerleme raporları incelenerek yapılmıştır. Değerleme raporlarının güncelliği açısından 2010 yılı sonrası raporlar incelemeye alınmıştır. Gayrimenkul değerleme raporları taşınmazın cinsine göre işyeri, arsa-tarla ve yapı olmak üzere üç temel gruba ayrıımıştır. Seçilen raporların özel bilgiler içermeyip, açıklanmış raporlar olmasına özen gösterilmiştir. Seçilen raporların grupların özelliklerini yansıtmaları için her grup için seçimler rastgele olarak ve değişik değerleme firmalarına ait değerleme raporlarından seçilmiştir.

Tablo 4: Araştırmaya Dâhil Edilen Taşınmazların Dağıııı

\begin{tabular}{|l|c|c|c|c|}
\hline Grup & İşyeri & Yapı & Arsa, Tarla & Tümü \\
\hline Taşınmaz Cinsi & 15 & 15 & 15 & 45 \\
\hline Değerleme Yapan Firmaların Sayısı & 11 & 10 & 10 & 19 \\
\hline
\end{tabular}

\section{BULGULAR VE TARTIŞMA,}

\subsection{Değerleme Raporlarında Kullanılan Değerleme Yöntemleri}

Tablo 5'te incelenen gayrimenkul değerleme raporlarında değerleme yöntemi olarak UDS' de yer alan yöntemlerden emsal karşılaştırma, maliyet ve gelir indirgeme yöntemi kullanıldığı gözlemlenilmiştir. Genelde pazar yaklaşımı yöntemi ya da emsal karşılaştırma yöntemi olarak tanımlanan yöntemin değerleme raporlarında yer aldığı görülmüştür. İkinci olarak yaygın 
olan değerleme yöntemi gelir indirgeme yöntemi olduğu gözlemlenmiştir. Maliyet yönteminin ise daha az kullanıldığı ve işyerleri ile yapılarda tercih edildiği görülmüştür. Pazar değerinde satılmak için birbirleri ile rekabet halinde olan gayrimenkullerin fiyatları üzerinde düzeltme çalışmaları yapılarak fiyatların oluşturulduğu, seçilen emsal fiyatlarının genelde var olan satış fiyatlarından alındığı az miktarda satışta olan emsal fiyatlarına göre hesaplandığı seçilen değerleme raporlarında gözlemlenilmiştir. Maliyet fiyatlarının hesabında piyasa ve kamu kaynaklı fiyatların kullanımının yaygın olduğu anlaşılmıştır.

Tablo 5: İncelenen Raporlarda Değerleme Yöntemleri

\begin{tabular}{|l|l|l|l|l|}
\hline Kullanılan Değerleme Yöntemi & Arsa, Tarla & İşyeri & Yapı & Tümü \\
\hline Emsal Karşılaştırma & $31 \%$ & $22 \%$ & $31 \%$ & $84 \%$ \\
\hline Maliyet Yöntemi & $0 \%$ & $11 \%$ & $7 \%$ & $47 \%$ \\
\hline Gelir İndirgeme & $18 \%$ & $31 \%$ & $18 \%$ & $67 \%$ \\
\hline Geliştirme, Diğer Yöntem & $7 \%$ & 0 & 0 & $7 \%$ \\
\hline
\end{tabular}

\subsection{Gayrimenkul Değerleme Raporlarında Kullanılan Değerleme Yöntem Sayısı}

Tablo 6' ye göre değerleme raporlarında iki adet değerleme yönteminin kullanımı çok yaygın olduğu, bir adet değerleme yönteminin de yaygın olarak kullanıldığı, üç adet değerleme yönteminin ise çok az kullanılmakta olduğu anlaşımaktadır. Genelde değeri yüksek olan projelerde en az iki değerleme yöntemi kullanılırken, değeri az olan taşınmazlarda bir ya da iki değerleme yönteminin kullanımının yaygın olduğu gözlemlenmekte olup bu durum maliyetle ilişkili olarak yorumlanabilir.

Tablo 6: Değerleme Raporlarında Kullanılan Değerleme Yöntem Sayısı

\begin{tabular}{|l|l|l|l|l|}
\hline Kullanılan Değerleme Yöntemi Sayısı & Arsa, Tarla & İşyeri & Yapı & Tümü \\
\hline 1 Adet Yöntem & $13 \%$ & $2 \%$ & $13 \%$ & $29 \%$ \\
\hline 2 Adet Yöntem & $18 \%$ & $31 \%$ & $18 \%$ & $67 \%$ \\
\hline 3 Adet Yöntem & $2 \%$ & $0 \%$ & $2 \%$ & $4 \%$ \\
\hline
\end{tabular}

\subsection{Gayrimenkul Değerleme Raporlarında Seçilen Değerleme Yöntemi}

Tablo 7' da Gayrimenkul değerleme uzmanının değerlendirmesine göre, değerleme yöntemlerinden seçilen değerleme yönteminin büyük çoğunlukla pazar değerini yansıtan Emsal Karşılaştırma Yönteminin seçildiği gözlemlenmektedir. İşyerlerinde az da olsa gelir indirgeme yönteminin seçildiği, uyumlaştırma dediğimiz değerin düzeltilmesinin de yaygın olarak kullanıldığı gözlemlenmiştir.

Tablo 7: Seçilen Değerleme Yöntemleri

\begin{tabular}{|l|c|c|c|c|}
\hline Seçilen Değerleme Yöntemi & Arsa, Tarla & İşyeri & Yapı & Tümü \\
\hline Emsal Karşılaştırma & $67 \%$ & $55 \%$ & $67 \%$ & $62 \%$ \\
\hline Maliyet & $0 \%$ & $0 \%$ & $11 \%$ & $4 \%$ \\
\hline Gelir İndirgeme & $0 \%$ & $9 \%$ & $0 \%$ & $4 \%$ \\
\hline Uyumlaştırma & $33 \%$ & $36 \%$ & $22 \%$ & $31 \%$ \\
\hline
\end{tabular}

\subsection{Değerleme Raporlarındaki Uyumlaştırmalardaki Kullanılan Değerleme Yöntemleri}

Değerleme raporlarında kullanılan değerleme yöntemlerinden seçim yapmayıp bulunan değere düzeltme yapılır, bazen yuvarlama, bazen ortalama bazen de aralıkta bir fiyat değerleme uzmanının tecrübesine, kanaatine ya da uyguladığı kriterlere göre seçilir. Uyumlaştırma işlemi değerleme raporlarında değil de bazı ek dokümanlarda açıklandığı, yapılan incelemelerde görülmüştür. Tablo 8' de uyumlaştırma dediğimiz fiyatı düzenlerken, genelde emsal karşılaştırmanın ve gelir indirgemenin seçildiğini bazen de maliyetin arada bir de geliştirme ve diğer yöntemlerin seçildiği, değerlerin uyumlaştırması genelde çok değerli taşınmazlarda yapıldığı gözlenmiştir.

Tablo 8: Uyumlaştırmadaki Kullanılan Değerleme Yöntemleri

\begin{tabular}{|l|l|l|l|l|}
\hline Adet & Emsal Karşılaştırma & Maliyet & Gelir İndirgeme & Geliştirme ve Diğer \\
\hline Tümü & $16 \%$ & $9 \%$ & $16 \%$ & $4 \%$ \\
\hline
\end{tabular}

\subsection{Kullanılan Değerleme Yöntemi Değerleri Arasındaki Fark}

Tablo 9' dan değerleme raporlarında kullanılan değerleme yöntemleri arasında farklar olabilmekte olduğu, bir değerleme yönteminin kullanımının da yaygın olduğu, farkın genelde $\% 10$ dan küçük olduğu, bir değerleme yönteminin 
kullanılmasından dolayı farkın sıfır çıktığı gözlemlenmiştir. Genelde çok değerli taşınmazlarda kullanılan farkın daha fazla olduğu, değeri az olan taşınmazlarda ise bir değerleme yöntemi kullanımının yaygın olduğu anlaşılmıştır.

Tablo 9: Kullanılan İki Değerleme Yöntemi Arasındaki Fark

\begin{tabular}{|l|c|c|c|c|}
\hline Fark & 0\% (1 yöntem) & \%1-\%9 & \%10-\%19 & \%20-fazlası \\
\hline İşyeri & $2 \%$ & $18 \%$ & $0 \%$ & $13 \%$ \\
\hline Yapı & $18 \%$ & $9 \%$ & $7 \%$ & $0 \%$ \\
\hline Arsa, Tarla & $13 \%$ & $9 \%$ & $4 \%$ & $7 \%$ \\
\hline Tümü & $33 \%$ & $36 \%$ & $11 \%$ & $20 \%$ \\
\hline
\end{tabular}

\subsection{Değerleme Raporlarında Emsal Fiyat Kaynakları}

Tablo $10^{\prime}$ da değerleme raporlarında emsal alınan fiyatlarda fiyatların nasıl seçildiği ile ilgili çalışma yapılmıştır. Emsal fiyatların satılan, kiralanan yani gerçekleşmiş fiyatlar değil aksine satılık, kiralık emsal fiyatların alındığı yani olası fiyatlar olduğu gözlemlenmektedir. Bunun sebebi tapu kayıtlarındaki, vergi dairesindeki fiyatların alınmamış ya da alınamamış olması ülkemizdeki tapu ve vergi kayıtlarının erişime açıklığı ve gerçeği yansıttığı kanaatinin zayıflı̆ından kaynaklandığı düşünülmektedir. Fiyatlar emlak işi ile uğraşanların yerine, belediyelerden, tapu dairelerinden, vergi dairelerinden daha güvenilir bilgi elde edilebilir. Belediye emlak vergisi kullanımının, tapu dairesinden alınan satış fiyatlarına çok az rastlanılmış olup genelde yapılan satışların duyum şeklinde etraftan öğrenildiği, incelenen değerleme raporlarından anlaşılmıştır.

Tablo 10: Değerleme Raporlarında Emsal Fiyatları Nasıl Seçilmiş

\begin{tabular}{|l|l|l|l|l|}
\hline Emsal Fiyatları Seçimi & Arsa, Tarla & İşyeri & Yapı & Tümü \\
\hline Satılmış Bilgisi & $20 \%$ & $4 \%$ & $11 \%$ & $36 \%$ \\
\hline Satılık Bilgisi & $27 \%$ & $33 \%$ & $33 \%$ & $93 \%$ \\
\hline Kiralık Bilgisi & $4 \%$ & $9 \%$ & $9 \%$ & $22 \%$ \\
\hline
\end{tabular}

\subsection{Değerleme Cinsine Göre Kullanılan Brüt Kira Çarpanı}

Tablo $11^{\prime}$ de incelenen gayrimenkul değerleme raporlarında, genelde işyerlerinde brüt kira çarpanlarının 10 ile 14 yıl arası alındığı, yapılarda 20 ile 24 yıl arası alındığı, arsa tarlalarda ise 20 ile 24 yıl alındığı görülmektedir. Değerleme raporlarının piyasa kabullerini ve beklentilerini yansıttığı kabul edilir. Değerleme raporlarındaki kapitalizasyon oranı ve brüt kira çarpanı enflasyona göre değil taşınmazın cinsine ve kullanım amacına bağlı olarak değiştiği gözlemlenmiştir. Yapılan incelemede ıskonto oranlarında, farklı oranların hesaplanabildiği detaylı olarak açıklanmadığı gözlemlenmiştir. Resmi standart bir oranın alınmadığı gözlemlenmiştir.

Tablo 11: Değerleme Cinsine Göre Bulunan Yıl Olarak Kira Çarpanı

\begin{tabular}{|l|c|c|c|c|}
\hline Kira Çarpanı Yıl & $\mathbf{5 - 9}$ yıl & $\mathbf{1 0 - 1 4}$ yıl & $\mathbf{1 5 - 1 9}$ yıl & $\mathbf{2 0 - 2 4}$ yıl \\
\hline İşyeri & $0 \%$ & $22 \%$ & $4 \%$ & $0 \%$ \\
\hline Yapı & $0 \%$ & $2 \%$ & $4 \%$ & $7 \%$ \\
\hline Arsa, Tarla & $7 \%$ & $2 \%$ & $0 \%$ & $2 \%$ \\
\hline Tümü & $7 \%$ & $27 \%$ & $9 \%$ & $9 \%$ \\
\hline Kapitalizasyon Oranı & $14,3 \%$ & $8,0 \%$ & $5,7 \%$ & $4,4 \%$ \\
\hline
\end{tabular}

\subsection{Raporlardaki Fotoğraf ve Uydu Fotoğrafların Kullanılması}

Tablo 12' da değerleme raporlarında fotoğraf ve uydu fotoğrafı kullanılması oranı gayrimenkul değerlemenin masa başımı yoksa yerinde gözlemlenerek mi yapıldığı konusunda fikir vermesi açısından incelenmiştir. Gayrimenkulün fotoğrafının bulunması mecburi olmadığı fakat faydalı bir uygulama olduğu değerlendirilmektedir.

Tablo 12: Raporlarda Taşınmazın Fotoğrafı veya Uydu Fotoğrafı Varlığı

\begin{tabular}{|l|l|l|l|l|}
\hline Değerleme Raporunda & Arsa, Tarla & İşyeri & Yapı & Tümü \\
\hline Fotoğraf var $\mathbf{m ı}$ & $20 \%$ & $13 \%$ & $27 \%$ & $60 \%$ \\
\hline Uydu fotoğrafı var $\mathbf{m ı}$ & $24 \%$ & $20 \%$ & $31 \%$ & $76 \%$ \\
\hline
\end{tabular}

\section{SONUÇ}

Ülkemizdeki mevzuata göre değerleme ile ilgili kurumlar SPK tarafından denetlenmektedir, fakat değerleme raporları çok değişik amaçlarla farklı mevzuata tabi kuruluşlarca kullanılmakta olduğundan karmaşıklıklara ve düzensizliklere yol açmaktadır bu nedenle Ticaret Kanunu ve diğer ilgili mevzuatta değişiklikler, yeni düzenlemeler gerekmektedir. Ticari 
hayatta gayrimenkul değerlemede etik olmayan davranışların yapıldığı duyulmakta olup değerleme konusu hassas ve maddi açıdan çıkar elde etmeye müsait bir alan olduğundan yeni önlemler alınması, SPK kapsamı dışında da denetlemeleri yapan bir kurumun varlığı gereklidir. UDS standartlarının kullanılması KGK gibi yetki alanı geniş bir kamu kuruluşunun görevi olmalıdır ya da standartlar ile ilgili Türkiye Değerleme Uzmanları Birliğine diğer kanunlarla da gerekli yetkiler verilmelidir. 2006 da UDS standartları ile ilgili tebliğ çıkaran SPK ancak 2017' de UDS' yi güncellemiştir. 2017' deki tebliğde 2013 yılı UDS kabul edilmiş olup bu olay yasal düzenlemelerin çarpıklığını gösteren en önemli göstergedir. İncelenen değerleme raporlarında SPK' nın standartları geç kabulü ile hala eski UDS ifadelerinin değerleme raporlarında kullanılmış olduğu gözlemlenmiştir. UFRS uygulamaları ile gayrimenkul değerleme raporlarının muhasebede kullanımları artmış fakat keyfi uygulamalar görülebilmekte olduğu gözlemlenmiştir. SPK kapsamına tabi olmayan alanlarda değerlemenin ne zaman, nerede, kim tarafından yapılacağı yasal mevzuatta karmaşıklıklara sebep olmaktadır, hatta değerlemelerin bağımsız denetim firmalarınca yetkisi olmayan bağımsız deneticiler tarafından yapılabildiği bilgilerine ulaşılmıştır. Bağımsız deneticinin değerlemeleri yapan değil, kontrol eden olduğu göz önüne alınırsa durumun suiistimal edilebilirliği tehlikesi olduğu anlaşılmaktadır. Bu durumun KGK tarafından düzenlenmesinde fayda olacağı önerilmektedir. Vergiyi azaltmak ya da işletmenin finansal tablolarının yatırımcıları aldatmak amaçlı kullanılmasının önlenmesi gereklidir. Değerleme işinin gerçek gücünün piyasa verilerine dayandığı ve bu verilerin sağlıklı olması durumunda geçerli olacağı unutulmamalıdır. Tapuda değerin eksik bildirilmesi, az vergi ödemek için yapılan tapu kayıtlarının UDS' ye göre pazar fiyatlarını yansıtmadığı anlaşılmaktadır. Bu durum sebebiyle pazar fiyatlarının emlak işi ile uğraşanlardan elde edildiği, duyumlarla hareket edildiği, satılık taşınmazların fiyatlarının değerleme raporlarında emsal fiyat olarak kullanıldığı anlaşımaktadır. Bu durumun değerleme raporlarının güvenilirliğini olumsuz etkilemekte olup yeni hukuki düzenlemelerin yapılması gerekmektedir. Değerleme raporlarının incelenmesinde genelde zaman kısıtlaması olduğu anlaşılmaktadır. Raporlarda değerleme süreleri iki, üç gün olarak çok büyük projelerin ise dört gün olarak verildiği gözlemlenmiş olup bu sürelerin yeterli olmayacağı düşünülmektedir. Değerleme raporlarındaki taşınmazın fotoğraflarının olmaması, verilerin internetten sağlandığı ya da taşınmazın görülmeyip verilen evraklardan değerleme raporlarının yazıldığı izlenimine sebep olmaktadır. Bu durumun, yeni düzenlemeleri gerektirdiği anlaşıımaktadır. Değerleme raporlarında uzun ekonomik durumun anlatılması gereksiz ve aynı değerleme şirketine ait raporların benzer bilgiler içermesine sebep olmakta olup değerleme raporlarının etkinliğini azaltmaktadır. Değerleme raporların şirketlere göre değiştiği, aynı şirketin aynı tür değerleme raporları yaptığı görülmüştür, raporların şirketlere göre değil değerleme amaçlarına uygun olarak düzenlenmesi gerekmektedir.

\section{KAYNAKLAR}

Akbulut, A., (2011). TTK-VUK Defter ve Kayıt Düzeni ile Değerleme Karşılaştırmaları, Vergi Dünyası Sayı 355 Mart, İstanbul.

Çına Bal, E., (2015). TMS- 40 Yatırım Amaçlı Gayrimenkuller Standardına Göre Halka Açık Gayrimenkul Yatırım Ortaklıklarının Yatırım Amaçlı Gayrimenkullerini Değerleme Politikalarının İncelenmesi, İşletme Araştırmaları Dergisi, İstanbul.

Çil Koçyiğit, S., (2013). Borsada İşlem Gören Şirketlerde Finansal Tablolardaki Muhasebe Politikalarının TMS40 Açısından Değerlendirilmesi, Işletme Araştırmaları Dergisi, İstanbul.

Demir, E., (2017). İnşaat ve Gayrimenkul Muhasebesi, SPL Sermaye Piyasası Lisanslama Sicil ve Eğitim Kuruluşu, İstanbul.

Erer, M., Hazır, Ç.A., (2014). TFRS’ ye Göre Yatırım Amaçlı Gayrimenkullerin Muhasebeleştirilmesi ve Ölçülmesi, Çözüm Kasım Aralık, İstanbul.

Hacıköylü, C., Afşar, A, (2013). Emlak Finans ve Emlak Değerleme, Anadolu Üniversitesi Web-Ofset Tesisleri 1 Baskı, Eskişehir.

Hazar, A., (2013). Varlık Değerleme Yaklaşımları Çerçevesinde Gayrimenkul Değerleme, Seçkin Yayınevi, i̇stanbul.

Hepşen, A., (2015). Gayrimenkul Değerleme Esasları, SPL Sermaye Piyasası Lisanslama Sicil ve Eğitim Kuruluşu, İstanbul.

Katipoğlu, B., (2007). Gayrimenkul Değerleme Eğitimi Ders Notları, TMMOB Mimarlar Odası Sürekli Mesleki Gelişim Yayınları 3, Ankara.

Köktürk, E., (2009). Taşınmaz Değerleme Durum Saptaması ve Yönelimler, TMMMOB Harita Kadastro Mühendisleri Odası 12. Türkiye Harita Bilimsel ve Teknik Kurultayı, Ankara.

Önal, Y.B., (2008). Gayrimenkul Değerleme ve Önemi: Vergisel Açıdan Bir Değerlendirme, Muhasebe ve Denetime Bakış Dergisi Ocak, İstanbul.

Şengel, S., Ağca, A., (2013). İnşaat ve Gayrimenkul Muhasebesi, Anadolu Üniversitesi Web-Ofset Tesisleri, Eskişehir.

Tanrıvermiş, H., (2016). Gayrimenkul Değerleme Esasları, SPL Sermaye Piyasası Lisanslama Sicil ve Eğitim Kuruluşu, İstanbul.

Utkucu, T., (2007). Gayrimenkul Değerlemesinin Önemi ve Gayrimenkul Değerini Etkileyen Unsurlar, Vergi Dünyası Dergisi Ocak 2007, İstanbul.

SPK62.1, (2017). 62.1 sayılı Sermaye Piyasasında Değerleme Standartları Hakkında Tebliğ, http://www.spk.gov.tr/apps/ Mevzuat/?submenuheader=-1, Erişim Tarihi: 20170501.

UDS, (2017). Uluslar arası Değerleme Standartları SPK Tebliği, İstanbul, https://www.tspb.org.tr/wp-content/uploads/2017/02/Ek1UDS.pdf, Erişim Tarihi: 20170501.

Yetgin, F., (2009). Proje Değerleme: Örnek Uygulamalar ile Gayrimenkul Değerlemesi, Creative Yayıncılık ve Tanıtım Ltd. Şti, İstanbul.

Yomralıoğlu, T., Nişancı, R., Çete, M., Candaş, E., (2011). Dünya'da ve Türkiye'de taşınmaz değerlemesi, Türkiye' de Sürdürülebilir Arazi Yönetimi Çalıştayı 26-27 Mayıs 2011 Okan Üniversitesi, İstanbul. 